\title{
Karyotypic analyses and morphological comments on the endemic and endangered Brazilian painted tree rat Callistomys pictus (Rodentia, Echimyidae)
}

\author{
Karen Ventura ${ }^{1}$, Gilson Evaristo Iack Ximenes ${ }^{2}$, Renata Pardini ${ }^{3}$, Marcos A. Nóbrega de Sousa ${ }^{4}$, \\ Yatiyo Yonenaga-Yassuda ${ }^{1}$ and Maria José de J. Silva ${ }^{5}$ \\ ${ }^{1}$ Departamento de Genética e Biologia Evolutiva, Instituto de Biociências, Universidade de São Paulo, \\ São Paulo, SP, Brazil. \\ ${ }^{2}$ Departamento de Ciências Biológicas, Universidade Estadual de Santa Cruz, Ilhéus, BA, Brazil. \\ ${ }^{3}$ Departamento de Zoologia, Instituto de Biociencias, Universidade de São Paulo, São Paulo, SP, Brazil. \\ ${ }^{4}$ Centro de Ciências Biológicas e Sociais Aplicadas, Universidade Estadual da Paraíba, João Pessoa, \\ PB, Brazil. \\ ${ }^{5}$ Laboratório Especial de Ecologia e Evolução, Instituto Butantan, São Paulo, SP, Brazil.
}

\begin{abstract}
The genus Callistomys belongs to the rodent family Echimyidae, subfamily Echimyinae, and its only living representative is Callistomys pictus, a rare and vulnerable endemic species of the state of Bahia, Brazil. Callistomys has been previously classified as Nelomys, Loncheres, Isothrix and Echimys. In this paper we present the karyotype of Callistomys pictus, including CBG and GTG-banding patterns and silver staining of the nucleolus organizer regions (Ag-NORs). Comments on Callistomys pictus morphological traits and a compilation of Echimyinae chromosomal data are also included. Our analyses revealed that Callistomys can be recognized both by its distintinctive morphology and by its karyotype.
\end{abstract}

Key words: Callistomys, karyotype, banding patterns, Echimyinae.

Received: September 28, 2007; Accepted: March 17, 2008.

The Neotropical spiny rats of the family Echimyidae comprise approximately 85 recognized living species grouped in 21 genera (modified from McKenna and Bell, 1997; Woods and Kilpatrick, 2005; Emmons, 2005; IackXimenes et al., 2005). Echimyids have a wide distribution, ranging from Southern Paraguay to Southern Nicaragua (Anderson and Jones, 1967; Honacki et al., 1982; Hartenberger, 1985). They are the most diverse of all living hystricognath rodents and the evolutionary relationships among genera are still unclear due to the paucity of data regarding their ecology, diversity and systematics (Leite and Patton, 2002; Woods and Kilpatrick, 2005).

Woods and Kilpatrick (2005) recognized four Echimyidae subfamilies: (1) the extinct Heteropsomyinae, endemic to West India; (2) Dactylomyinae, including the arboreal bamboo rats from the genera Dactylomys, Kannabateomys and Olallamys; (3) Echimyinae, including

Send correspondence to Maria José de Jesus Silva. Laboratório Especial de Ecologia e Evolução, Instituto Butantan, Av. Dr. Vital Brazil 1500, 05503-900 São Paulo, SP, Brazil. E-mail: mariajo@ butantan.gov.br or mariajo@usp.br. the arboreal genera Callistomys, Diplomys, Echimys, Phyllomys, Isothrix and Makalata; and (4) Eumysopinae, including the semi-fossorial, arboreal and terrestrial genera Carterodon, Clyomys, Euryzygomatomys, Lonchothrix, Mesomys, Hoplomys, Proechimys, Trinomys and Thrichomys. Since then, several new genera of Echimyinae have been erected: Pattonomys to include Nelomys semivillosus Geoffroy, 1838 and allied species, Santamartamys to include Isothrix rufodorsalis Allen, 1899 (Emmons, 2005) and Toromys to include Loncheres grandis Wagner 1845 (Iack-Ximenes et al., 2005).

Karyotypes of Echimyinae are known only for Pattonomys semivillosus and for some species of Phyllomys, Makalata and Isothrix and their chromosome numbers ranged from $2 \mathrm{n}=22$ in Isothrix pagurus to $2 \mathrm{n}=96$ in Phyllomys medius (Table 1).

The painted tree rat or cocoa rat Callistomys pictus (Pictet, 1843) is a soft-furred echimyid found in the coast of the state of Bahia, Northeastern Brazil. It was originally included in the genus Nelomys as a junior synonym of Echimys. It was afterwards alternatively classified as 
Table 1 - Karyotypes of Echimyinae taxa (Suborder Hystricognathi).

\begin{tabular}{|c|c|c|c|c|c|}
\hline Taxa & Referred as & $2 n$ & $\mathrm{FN}$ & Locality & Reference \\
\hline Callistomys pictus & & 42 & 76 & Ilhéus, BA, Brazil & Present paper \\
\hline Pattonomys semivillosus & Echimys semivillosus & 94 & 114 & Venezuela & $\begin{array}{l}\text { Aguilera et al., 1998; } \\
\text { Emmons, } 2005\end{array}$ \\
\hline Isothrix bistriata & & 60 & 116 & $\begin{array}{l}\text { Rio Juruá, AC and UHE } \\
\text { Samuel, RO, Brazil }\end{array}$ & $\begin{array}{l}\text { Patton et al., 2000; } \\
\text { Leal-Mesquita, 1991* }\end{array}$ \\
\hline I. negrensis & & 60 & 112 & Rio Negro, AM, Brazil & Bonvicino et al., 2003 \\
\hline I. pagurus & & 22 & 38 & Manaus, AM, Brazil & Patton and Emmons, 1985 \\
\hline I. sinnamariensis & & 28 & 42 & French Guiana & Vié et al., 1996 \\
\hline Makalata sp. & Makalata armata & 70 & 120 & UHE Samuel, RO, Brazil & Leal-Mesquita, 1991* \\
\hline Makalata didelphoides & & 66 & 106 & $\begin{array}{l}\text { Balbina Hydroeletric Dam on } \\
\text { the Uatumã River, AM, } \\
\text { Brazil }\end{array}$ & Lima et al., 1998 \\
\hline Phyllomys blainvilli & & 50 & 94 & BA and PE, Brazil & $\begin{array}{l}\text { Souza, 1981* apud } \\
\text { Leite, 2003; Leite, } 2003\end{array}$ \\
\hline P. dasythrix & & 72 & ND & RS, Brazil & Leite, 2003 \\
\hline$P$. aff. dasythix & Echimys sp. & $90 / 92$ & ND & SP and RS, Brazil & Yonenaga, 1975; Leite, 2003 \\
\hline P. medius & Echimys dasythrix & 96 & ND & SC, Brazil & $\begin{array}{l}\text { Sbalqueiro, } 1998 \text { apud Leite, } \\
2003\end{array}$ \\
\hline P. nigrispinus & & 52 & ND & RJ, Brazil & Leite, 2003 \\
\hline P. pattoni & Echimys sp. / E. thomasi & $80 / 72$ & $112 / 114$ & ES and RJ, Brazil & $\begin{array}{l}\text { Zanchin, } 1988^{\&} \text { apud Leite, } \\
2003\end{array}$ \\
\hline
\end{tabular}

$\mathrm{FN}=$ autosomal fundamental number; $\mathrm{ND}=$ not described. Abbreviations of Brazilian States: $\mathrm{AC}=\mathrm{Acre} ; \mathrm{AM}=\mathrm{Amazonas} ; \mathrm{BA}=\mathrm{Bahia} ; \mathrm{ES}=\mathrm{Espírito}$ Santo; $\mathrm{PE}=$ Pernambuco; RJ = Rio de Janeiro; RO = Rondônia; RS = Rio Grande do Sul; $\mathrm{SC}=$ Santa Catarina; $\mathrm{SP}=$ São Paulo; UHE = Usina Hidrelétrica. *Leal-Mesquita ERRB (1991) Estudos citogenéticos em dez espécies de roedores brasileiros da família Echimyidae. MSc dissertation. Departamento de Biologia, Instituto de Biociências, Universidade de São Paulo, São Paulo, Brazil; " Souza MJ (1981) Caracterização cromossômica em oito espécies de roedores brasileiros das famílias Cricetidae e Echimyidae. Ph.D. thesis. Departamento de Biologia, Instituto de Biociências, Universidade de São Paulo. São Paulo, Brazil; 'Zanchin NIT (1988) Estudos cromossômicos em orizominos e equimídeos da Mata Atlântica. Porto Alegre. MSc dissertation. Instituto de Biociências. Universidade Federal do Rio Grande do Sul. Porto Alegre, RS, Brazil.

Nelomys (Pictet, 1843; Goldman, 1916; Thomas, 1916), Echimys (Tate, 1935; Moojen, 1952) and Isothrix (Waterhouse, 1848; Ellerman, 1940; Cabrera, 1961; Honacki et al., 1982; Patton and Emmons, 1985) and it has only recently been placed in its own genus Callistomys (Emmons and Vucetich, 1998).

In a review of the genus Isothrix, Patton and Emmons (1985) followed Cabrera (1961) and Honacki et al. (1982) and kept Nelomys pictus within Isothrix. The same I. pictus was later classified as Nelomys (Emmons and Feer, 1990) and then included in Echimys (Woods, 1993; Emmons and Feer, 1997). Emmons and Vucetich (1998) examined the fossil mandible of one specimen identified as Lasiuromys villosus (a synonym of Isothrix bistriata) by Winge (1888) and several specimens of Nelomys pictus (including the holotype) and concluded that they belonged to the same genus. A comparison of these specimens with the three genera in which Nelomys pictus had been previously included led Emmons and Vucetich (1998) to conclude that N. pictus did not belong to any of them. Considering its distinct morphology, these authors suggested a new genus, Callistomys, to contain $N$. pictus and Callistomys sp. (formerly identified as Lasiuromys villosus).
Here we report new cytogenetic data on the endemic, rare and endangered Echimyinae Callistomys pictus, including Ag-NOR staining, CBG- and GTG-banding, as well as comments on the external morphology, cranial anatomy and geographical distribution of the species.

The specimen reported herein was incidentally captured in April 2002, preyed and injured by a domestic dog in a cacao plantation at Fazenda Santo Antônio (1441'46" S, 39¹5'22" W), Ilhéus, state of Bahia, Brazil. Ilhéus is the type-locality of Nelomys pictus Pictet, 1843. The animal was sacrificed according to Ethical Issues in the Use of Animals (Colégio Brasileiro de Experimentação Animal, COBEA, 1991), tissues were deposited in the collection of the Instituto de Biociências, Universidade de São Paulo (IBUSP) and the voucher specimen was deposited at the Museu de Zoologia, Universidade de São Paulo (MZUSP), São Paulo, Brazil, under the number MZUSP 31404.

Morphology - We employed Wahlert (1974, 1983, 1985) and Woods and Howlands (1979) for the nomenclature of cranial foramina. Dental nomenclature followed Iack-Ximenes et al. (2005) which was modified from Lavocat (1976) with further considerations from Butler (1985), Jaeger et al. (1985), Flynn et al. (1986), Jaeger 
(1989), Bryant and McKenna (1995), and Candela (1999a; 1999b; 2002). Besides the specimen from Fazenda Santo Antônio, Ilhéus, state of Bahia, eight other specimens of Callistomys pictus were examined, as follows: Brazil: Bahia: South America: NHM: 52.1.5.22 (skull, mounted skin) and 80.9.15.1 (skull, mounted skin); Brésil: MHNN: 94.2464A (mounted skin) and 94.2463 (mounted skin); Fazenda 7 Voltas, Ilhéus, Bahia: MZUSP: 31404 (skeleton, skin); Lavapés de Dentro, Rio do Braço, Bahia: MN: 11207 (skin, skull); Ilhéus, Bahia: MN15453 (skin, skull) and 31546 (skin, skull); no locality: MNK: 4809 (skull, skin) (Abbreviations: NHM: Natural History Museum, London, England; MHNN: Museum d'Histoire Naturelle du Neuchatel, Neuchatel, Switzerland; MZUSP: Museu de Zoologia, Universidade de São Paulo, São Paulo, Brazil; MNK - Museum für Naturkunde, Berlin, Germany, MN: Museu Nacional do Rio de Janeiro, Universidade Federal do Rio de Janeiro, Rio de Janeiro, Brazil).

External morphology: fur includes only soft hairs; hairs brown at base with tip white or black. Pelage is dense and long. Callistomys has a unique color pattern among echimyid rats: body white with black coat, extending from the top of head, nape, and back to the basis of tail. Tail densely haired, black at base and white distally. Limbs broad and stout, hands and feet relatively short but broad. Cranial anatomy: Skull is large and strong, rostrum and nasals medium sized and broad. Lateral wings of frontal well-developed forming a roof over orbital region; postorbital process of zygoma rounded and formed by squamosal. Petrosal bone covered by squamosal posteriorly. Incisive foramina long and fusiform, mostly formed by premaxillar. Septum of incisive foramina wide and long and formed by premaxillar. Palatal region rectangular, long and slender; palatine extending up to M1. Sphenopalatine foramen double. Mesopterygoyd fossae with slit-shaped lateral openings. Alisphenoid region wide; alisphenoid channel not differentiated; buccinator and masticator foramina confluents; foramen ovale medium sized; maxillary vein passes through foramina; transverse canal foramen well-developed. Bullae round, inflated, with tiny stiliform process, tegmen timpani short and wide; external auditory meatus opening in a short and strong tube. Upper molariforms tetralophodonts; anteroloph and the fourth loph (metaloph+protoloph) connected lingually as well as mesoloph and posteroloph. In young adults and younger specimens hypoflexus and mesoflexus deep, isolates anteroloph protoloph U-shaped from mesoloph posteroloph; but in older ones, the M1-M3 with narrow mure connecting protocone to hypocone. Lower molar trilophodonts and $\mathrm{dP} 4$ tetralophodont with metafossetid between first loph (anterolophid+metalophid) and mesolophid; mesolophid connected by mure to hipolophid; hipolophid and posterolophid connected labially by hipoconid.

Distribution - Callistomys pictus occurs in Bahia State, Brazil, and most records are from the municipality of
Ilhéus and nearby areas (Moojen, 1952; Emmons and Vucetich, 1998; Vaz, 2002, 2005). C. pictus was recently recorded in Serra da Jibóia, Elisio Medrado, Bahia State, about $150 \mathrm{~km}$ North of Ilhéus (Encarnação et al., 2000). Two specimens were collected by Auguste de Meuron, a tobacco dealer, and the locality was labeled as "Brésil". De Meuron lived in the city of Salvador, formerly known as Bahia, a name now used for the state. In view of the specimens from other species (P. pattoni, T. setosus) sent by de Meuron to the MHNN, it is possible that the specimens of Callistomys pictus came from Salvador (MHNN: 94.2464A and 94.2463) or from somewhere in the neighbourhood. Callistomys pictus is endemic to the Atlantic forest of the state of Bahia, Brazil, where it is also found in cacao plantations shaded by native trees. C. pictus is either locally rare or difficult to capture with traditional live trapping methods, since ecological studies with a high sampling effort carried out in different habitats in South Bahia did not record the species (Pardini, 2004; Moura RT, 1999, MSc Dissertation, Universidade Federal de Minas Gerais, BH, Brazil). Nevertheless, Callistomys pictus seems to be more common in cacao plantations in Ilhéus, where local people reported frequent sightings of the animal.

Cytogenetics - Metaphases from the male of Callistomys pictus were obtained from bone marrow and spleen 40 min after an in vivo subcutaneous injection of $0.1 \%$ colchicine. Conventional staining with Giemsa, AgNORs staining (Howell and Black, 1980), GTG- (Seabright, 1971) and CBG-banding (Sumner, 1972) were carried out following standard cytogenetic procedures.

The karyotype of Callistomys pictus revealed $2 \mathrm{n}=42$ and FN (number of autosomal arms) $=76$ (Figure 1A) and consisted of 18 pairs of meta or submetacentric autosomes decreasing in size (pair 1 to 16,18 and 20) and two pairs of small acrocentrics (17 and 19). The $\mathrm{X}$ and $\mathrm{Y}$ chromosomes were, respectively, medium and small acrocentrics; the $\mathrm{X}$ being perfectly distinguishable as a medium sized acrocentric. GBG-banding allowed the recognition of all autosome pairs and the sex chromosomes (Figure 1B). CBGbanding evidenced small heterochromatic blocks in the pericentromeric regions of some autosomes and in the sex chromosomes (Figure 2A). The single Ag-NOR was detected in a secondary constriction at the long arm of pair 13 (Figure 2B).

Callistomys pictus, the only living species of the genus, differs from other extant Echimyidae in many major cranial characters and could represent the last survivor of an old clade of Echimyinae. Other species of this genus represented by a single fossil from the Upper Pleistocene-Recent collected at Lapa do Capão Seco, Lagoa Santa, Minas Gerais State, Brazil, was recognized (Emmons and Vucetich, 1998). A cladistic analysis based on morphological data of Echimyidae placed Callistomys in the basal position of the Dactylomyinae/Echimyinae clade (Carvalho and Salles, 2004). The authors found a 
A
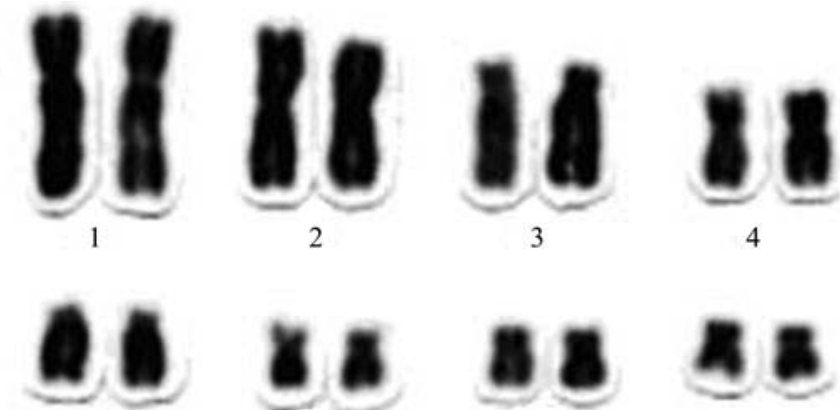

10

8
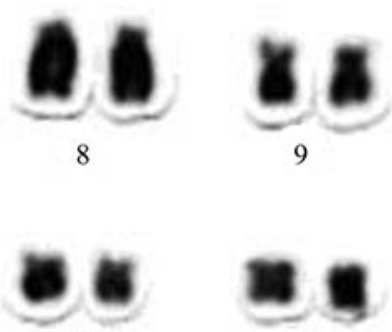

15
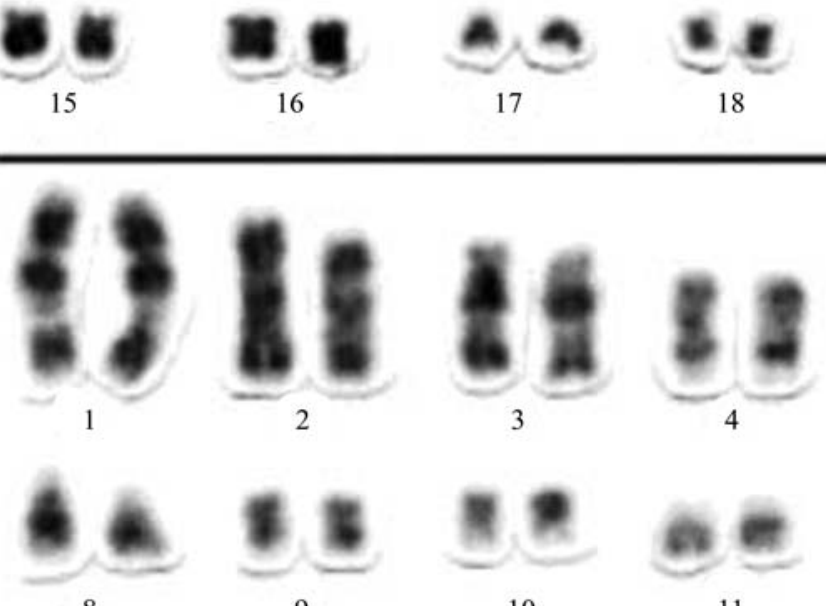

10
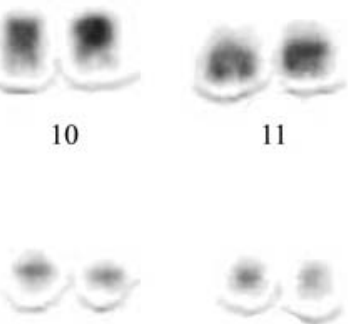

17
4

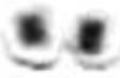

18
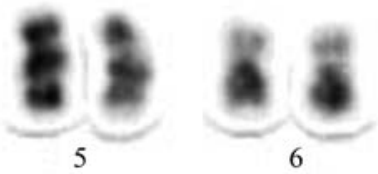

11
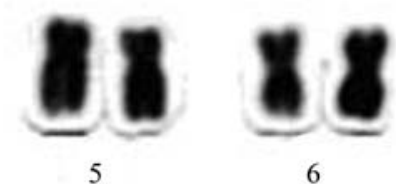

6

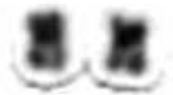

13
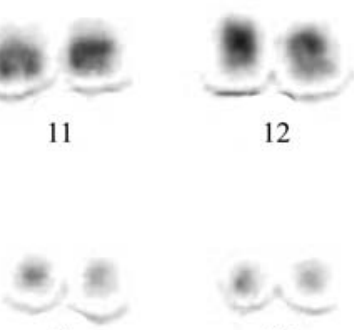

18
12

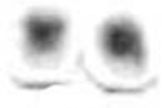

13

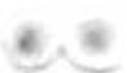

19

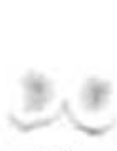

20
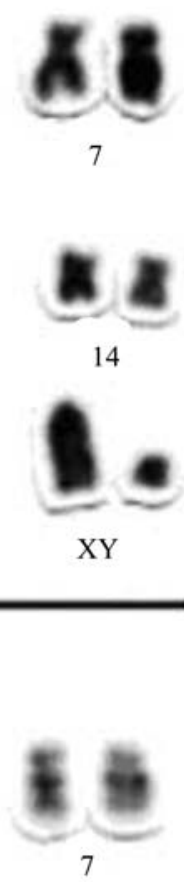

14
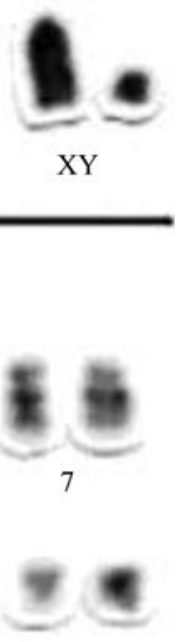

14

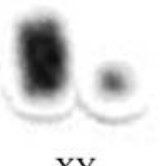

XY

Figure 1 - Karyotype of a male Callistomys pictus with $2 \mathrm{n}=42$ and $\mathrm{FN}=76$ after: (A) Conventional staining and (B) GTG-banding.

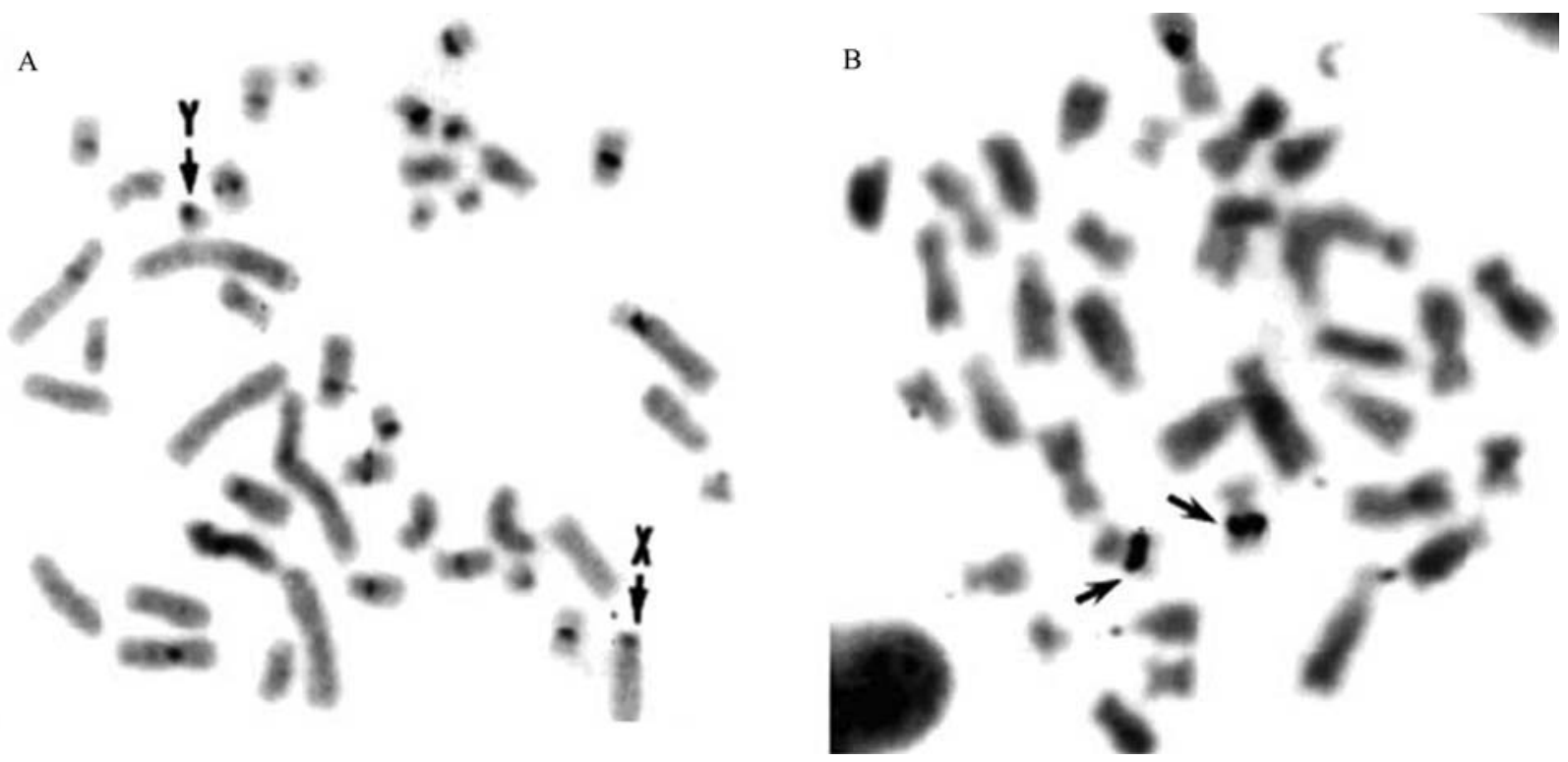

Figure 2 - Metaphases of Callistomys pictus after: (A) CBG-banding, arrows indicate the X and Y chromosomes and (B) Ag-NORs, arrows indicate the NOR-bearing pair 13. 


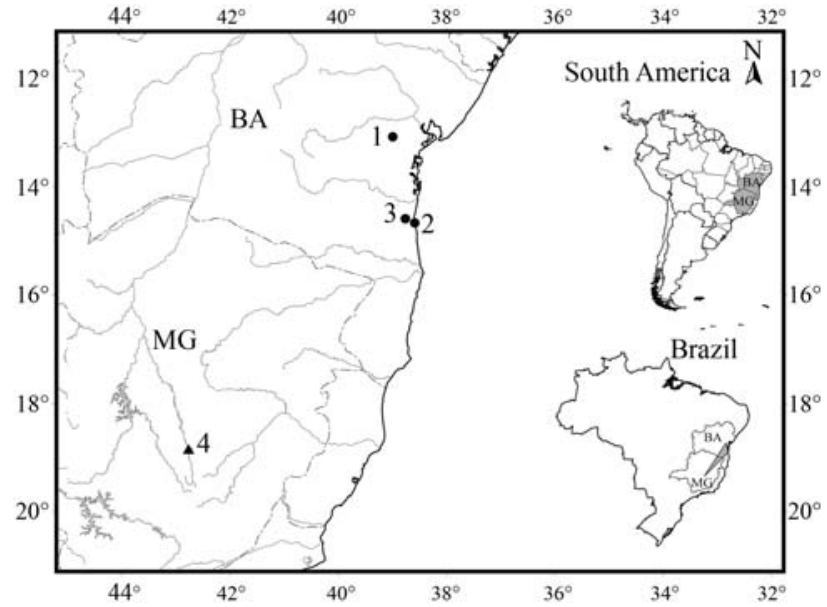

Figure 3 - Geographic distribution of Callistomys: (•) Callistomys pictus; ( $\mathbf{\Delta}$ ) Callistomys sp. 1) The states of Bahia (BA) and Minas Gerais (MG) are indicated on the right in the maps of South America and Brazil. Specific localities in Bahia (1-3) and Minas Gerais (4) are indicated on the left side of the map: 1. Elísio Medrado (12 $\left.56^{\prime} 47^{\prime \prime} \mathrm{S}, 39^{\circ} 31^{\prime} 18^{\prime \prime} \mathrm{W}, 390 \mathrm{~m}\right)$; 2. Ilhéus $\left(14^{\circ} 47^{\prime} 20^{\prime \prime} \mathrm{S}, 39^{\circ} 02^{\prime} 58^{\prime \prime} \mathrm{W}, 52 \mathrm{~m}\right)$; 3. Rio do Braço $\left(14^{\circ} 40^{\prime} 35^{\prime \prime} \mathrm{S}\right.$,

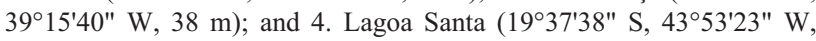
$760 \mathrm{~m})$.

slightly distinct topology when fossil taxa were included: Callistomys, Maruchito trilofodonte Vucetich et al., 1993 (a fossil echimyid genus from Middle Miocene), and the Dactylomyinae/Echimyinae formed a basal politomy. These results suggest that Maruchito and Callistomys can be related, as previously proposed by Emmons and Vucetich (1998). Callistomys occurs in the Bahia State of Brazil and is restricted to the Atlantic Forest in a few localities from Ilhéus to Elísio Medrado. Subfossil specimens from Minas Gerais were collected by Lund and the genus does not seem to presently occur near Lagoa Santa (Emmons and Vucetich, 1998), suggesting a recent reduction in its geographic distribution (Figure 3). Records of Callistomys pictus from Lagoa Santa are restricted to Pleistocene fossil specimens.

The taxonomy of Echimyinae is still very complex and the diploid numbers can be helpful in species identification since karyotypes seem to be important diagnostic markers (Table 1), except for Isothrix bistriata, I. negrensis and Echimys sp. with $2 \mathrm{n}=90 / 92$. Diploid numbers within Echimyinae are usually high, with the exception of Isothrix pagurus and $I$. sinnamariensis, with $2 \mathrm{n}=22$ and $2 \mathrm{n}=28$, respectively (Patton and Emmons, 1985; Vié et al., 1996), and of the odd $2 \mathrm{n}=42$ and $\mathrm{FN}=76$ described herein for Callistomys pictus.

Our results show that the karyotype associated to the restricted geographical range and the unique set of morphological traits are useful in identifying Callistomys pictus. Our data bring important new information thus reducing the knowledge gap of Brazilian biodiversity and, most importantly, contributing to improve conservation and management initiatives. This is specially important for species like Callistomys pictus, which was included as vulnerable in the red list of endangered species published by the Brazilian Institute for Environment (Instituto Brasileiro do Meio Ambiente e dos Recursos Naturais Renováveis, IBAMA) in 2003. In fact, as pointed out by Costa et al. (2005), the major threat to endangered small mammals is the scarcity of scientific knowlegde about their distribution, systematics, taxonomy and natural history, since most of them are rare and poorly known and very few sites of Brazil have been adequately surveyed.

\section{Acknowledgments}

The authors are grateful to George Mendes Taliaferro Mattox and the GMB Editor for the English and critical review, to Glaciene Tomaz de Oliveira for technical assistance, and to José Mário Beloti Ghelleri, Kenji Kato, Mateus Paciência, Ricardo Braga Neto, Sergio Souza and Alexandre Percequillo for fieldwork support and logistics. Grants from the Conselho Nacional de Desenvolvimento Científico e Tecnológico (CNPq) and Fundação de Amparo à Pesquisa do Estado de São Paulo (FAPESP; \# $1999 / 11.653-6$ to YYY and 2005/04557-3 to MJJS) are also acknowledged.

\section{References}

Aguilera M, Sangines N and Pérez-Zapata A (1998) Echimys semivillosus, a rodent with a very high chromosomal number. Caryologia 51:181-187.

Anderson S and Jones Jr JK (1967) Recent Mammals of the World - A Synopsis of Families. Ronald Press Co., New York, $453 \mathrm{pp}$.

Bonvicino CR, Menezes AREAN and Oliveira JA (2003) Molecular and karyologic variation in the genus Isothrix (Rodentia, Echimyidae). Hereditas 139:206-211.

Bryant JD and McKenna MC (1995) Cranial Anatomy and phylogenetic position of Tsaganomys altaicus (Mammalia, Rodentia) from the Hsanda Gol Formation (Oligocene), Mongolia. Am Mus Novit 3156:1-42.

Butler PM (1985) Homologies of molar cusps and crests, and their bearing on assesments of rodent morphology. In: Luckett WP and Hartenberger JL (eds) Evolutionary Relationships Among Rodents: A Multidisciplinary Analysis. Plenum Press, New York, pp 381-401.

Cabrera A (1961) Catálogo de los mamiferos de América del Sur. Rev Mus Arg Cienc Nat Bernadino Rivadavia 4:310-732.

Candela AM (1999a) Los Erethizontidae (Rodentia, Hystricognathi) Fósiles de Argentina. Sistemática e História Evolutiva y Biogeográfica (Abstract in English). Universidad Nacional de La Plata, La Plata, pp 192-202.

Candela AM (1999b) The evolution of the molar pattern of the Erethizontidae (Rodentia, Hystricognathi) and the validity of Parasteiromys Ameghino, 1904. Palaeovertebrata 28:53-73.

Candela AM (2002) Lower deciduous tooth homologies in Erethizontidae (Rodentia, Hystricognathi): Evolutionary significance. Acta Paleontol Polonica 47:717-723. 
Carvalho G and Salles LO (2004) Relationships among extant and fossil echimyids (Rodentia, Hystricognathi). Zool J Linn Soc Lond 142:445-477.

Costa LP, Leite YLR, Mendes SL and Ditchfield AD (2005) Mammal conservation in Brazil. Conserv Biol 19:672-679.

Ellerman JR (1940) The Families and Genera of Living Rodents. With a List of Named Forms (1758-1936) by RW Hayman and GWC Holt. v. I. Rodents other than Muridae. Trustees British Mus London, London, 689 pp.

Emmons LH (2005) A revision of the genera of arboreal Echimyidae (Rodentia, Echimyidae, Echimyinae); with description of two new genera. Zoology 133:247-310.

Emmons LH and Feer F (1990) Neotropical Rainforest Mammals - A Guide Field. University of Chicago Press, Chicago, $281 \mathrm{pp}$.

Emmons LH and Feer F (1997) Neotropical Rainforest Mammals - A Guide Field. 2nd ed. University of Chicago Press, Chicago, $307 \mathrm{pp}$.

Emmons LH and Vucetich MG (1998) The identity of Winge's Lasiuromys villosus and the description of a new genus of echimyid rodent (Rodentia, Echimyidae). Am Mus Novit 3223:1-12.

Encarnação AMV, Moraes EPF and Freitas MA (2000) Nova ocorrência de Callistomys pictus (Rodentia; Echimyidae) e aspectos de sua história natural (Abstract in English). Agrotrópica 12:65-66.

Flynn LJ, Jacobs LL and Cheema IU (1986) Baluchimyinae, a new ctenodactyloid rodent subfamily from the Miocene of Baluchistan. Am Mus Novit 2841:1-58.

Goldman EA (1916) Notes on the genera Isothrix Wagner and Phyllomys Lund. Proc Biol Soc Wash 29:125-128.

Hartenberger JL (1985) The order Rodentia major questions on their evolutionary origin, relationships and suprafamilial systematics. In: Luckett WP and Hartenberger JL (eds) Evolutionary Relationships Among Rodents - A Multidisciplinary Analysis. Plenum Press, New York and London, pp 1-16.

Honacki JH, Kinman EK and Koepel JW (1982) Mammal Species of the World: A Taxonomic and Geographic Reference. Allen Press and Association of Systematic Collections, Lawrence, $694 \mathrm{pp}$.

Howell WM and Black DA (1980) Controlled silver-staining of nucleolus organizer regions with protective colloidal developer: A 1st step method. Experientia 36:1014-1015.

Iack-Ximenes GE, Vivo M and Percequillo AR (2005) A new genus for Loncheres grandis Wagner, 1845, with taxonomic comments on other arboreal Echimyids (Rodentia, Echimyidae). Arq Mus Nac RJ 63:89-112.

Jaeger JJ (1989) L'évolution de la pentalophodontie chez les rongeurs Caviomorphes (Mammalia, Rodentia). Geobios Memoire Spéciale 12:235-244.

Jaeger JJ, Denis C and Coiffait B (1985) New Phiomorpha and Anomaluridae from the late Eocene of North-West Africa: Phylogenetics implications. In: Luckett WP and Hartenberger JL (eds) Evolutionary Relationships Among Rodents: A Multidisciplinary Analysis. Plenum Press, New York, pp 685-712.

Lavocat R (1976) Rongeurs caviomorphes de l'Oligocène de Bolivie. II Rongeurs du Bassin Deseadien de Salla-Luribay. Palaeovertebrata 7:15-90.
Leite YLR (2003) Evolution and systematics of the Atlantic tree rats, genus Phyllomys (Rodentia, Echimyidae), with description of two new species. Zoology 132:1-118.

Leite YLR and Patton JL (2002) Evolution of South American spiny rats (Rodentia, Echimyidae): The star-phylogeny hypothesis revisited. Mol Phylogenet Evol 25:455-464.

Lima JFS, Langguth A and Souza LC (1998) The karyotype of Makalata didelphoides (Rodentia, Echimyidae). Z Säugetierkunde 63:315-318.

McKenna MC and Bell SK (1997) Classification of Mammals Above the Species Level. Columbia University Press, New York, 640 pp.

Moojen JO (1952) Os Roedores do Brasil. Instituto Nacional do Livro e Biblioteca Científica Brasileira, Rio de Janeiro, 214 pp.

Pardini R (2004) Effects of forest fragmentation on small mammals in an Atlantic Forest landscape. Biodiv Conserv 13:2567-2586.

Patton JL and Emmons LH (1985) A review of genus Isothrix (Rodentia, Echimyidae). Am Mus Novit 2817:1-14.

Patton JL, da Silva MNF and Malcolm JR (2000) Mammals of the Rio Juruá: Evolutionary and ecological diversification of Amazonia. Bull Am Mus Nat Hist 244:1-306.

Pictet FJ (1843) Seconde notice sur les animaux nouveaux ou per connus du Musée de Genève. Mémoires de la Societé Physique d'Histoire Naturelle 10:201-213.

Sbalqueiro IJ, Severo JB, Oliveira LFB, Langguth AR, Zanchin NI, Nunes AP and Mattevi MS (1998) Os cariótipos de equimídeos brasileiros. Rev Bras Genet 21 (suppl):71.

Seabright M (1971) A rapid banding technique for human chromosomes. Lancet 2:971.

Sumner AT (1972) A simple technique for demonstrating centromeric heterochromatin. Expl Cell Res 75:304-306.

Tate GHH (1935) The taxonomy of genera of Neotropical hystricoid rodents. Bull Am Mus Nat Hist 68:295-447.

Thomas O (1916) On the generic names Rattus and Phyllomys. Ann Mag Nat Hist 8:240.

Vaz SM (2002) Sobre ocorrência de Callistomys pictus (Pictet) (Rodentia, Echimyidae) (Abstract in English). Rev Bras Zool 19:631-635.

Vaz SM (2005) Mamíferos colecionados pelo serviço de estudos e pesquisas sobre a febre amarela nos municípios de Ilhéus e Buerarema, estado da Bahia, Brasil (Abstract in english). Arq Mus Nac RJ 63:21-28.

Vié JC, Volobouev V and Patton JL (1996) A new species of Isothrix (Rodentia, Echimyidae) from French Guiana. Mammalia 60:393-406.

Vucetich MG, Mazoni, MM and Pardiñas FJ (1993) Los roedores de la formacion Collon Cura (Mioceno Medio) y la Ygnimbrita Pilcaniyeu, Cañadon del Trotillo, Neuquen (Abstract in English). Ameghiniana 30:361-381.

Wahlert JH (1974) The cranial foramina of protrogomorphous rodents; an anatomical and phylogenetic study. Bull Mus Comp Zool 113:113-214.

Wahlert JH (1983) Relationships of Florentiamyidae (Rodentia, Geomyidae) based on cranial and dental morphology. Am Mus Novit 2769:1-23.

Wahlert JH (1985) Cranial foramina of rodents. In: Luckett WP and Hartenberger JL (eds) Evolutionary Relationships Among Rodents: A Multidisciplinary Analysis. Plenum Press, New York, pp 311-333. 
Waterhouse GR (1848) A Natural History of the Mammalia. v. II. Containing the Order Rodentia or Gnawing Mammalia. Hyppolyte Baillière Publisher, London, 500 pp.

Winge (1888) Jordfundne og Nulevende gnavere (Rodentia) fra Lagoa Santa, Minas Geraes, Brasilien. E Museo Lundü $1: 1-178$.

Woods CA (1993) Hystricognathi. In: Wilson DE and Reeder DA (eds) Mammals Species of the World. A Taxonomic and Geographic Reference. 2nd ed. Smithsonian Institution Press and the American Society of Mammalogists, Washington, pp 771-806.

Woods CA and Howlands EB (1979) Adaptative radiation of Capromyid rodents: Anatomy of the masticatory apparatus. J Mamm 60:95-116.

Woods CA and Kilpatrick CW (2005) Infraorder Hystricognathi. In: Wilson DE and Reeder DA (eds) Mammals Species of the World. A Taxonomic and Geographic Reference. 2nd ed. Smithsonian Institution, Washington, $2142 \mathrm{pp}$.
Yonenaga Y (1975) Karyotypes and chromosome polymorphism in Brazilian rodents. Caryologia 28:269-286.

\section{Internet Resources}

IBAMA (Instituto Brasileiro do Meio Ambiente e dos Recursos Naturais Renováveis) (2003) Lista das espécies da fauna brasileira ameaçadas de extinção. Ministério do Meio Ambiente, Brasília. http://www.mma.gov.br/port/sbf/fauna/index.cfm (January 29, 2008).

COBEA (Colégio Brasileiro de Experimentação Animal) (1991) Princípios éticos na experimentação animal. http://www. propp.ufms.br/bioetica/ceua/cobea.htm (May 25, 2008).

Associate Editor: Fausto Foresti

License information: This is an open-access article distributed under the terms of the Creative Commons Attribution License, which permits unrestricted use, distribution, and reproduction in any medium, provided the original work is properly cited. 